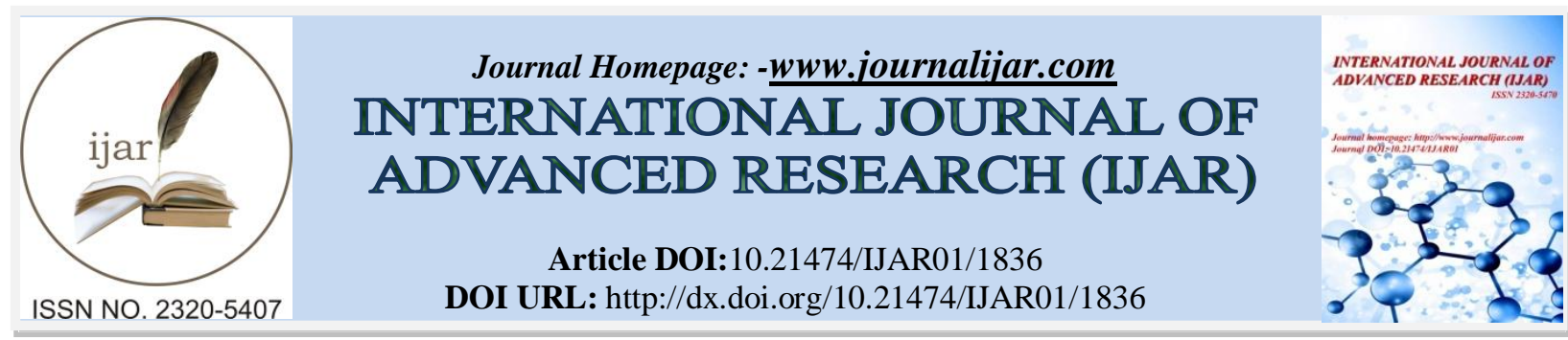

RESEARCH ARTICLE

\title{
POTENTIAL USE OF DATE PALMS AND COTTON STALKS BIOCHARS FOR REMOVING CO (II) AND NI (II) FROM WASTEWATER
}

\section{M. Khalil ${ }^{1}$, A. Osman ${ }^{2}$ and M. M. Mostafa ${ }^{2}$.}

1. Chemistry Department, Faculty of Science, Beni-Suef University, Beni-Suef, Egypt.

2. Soil, Water and Environment Research Institute (SWERI), Agriculture Researches Centre, Giza, Egypt.

\section{Manuscript Info}

\section{Manuscript History}

Received: 22 August 2016

Final Accepted: 23 September 2016

Published: October 2016

\section{Key words:-}

Wastewater, bio-sorbents,active carbon, and $\mathrm{pH}$ value.

\section{Abstract}

In recent years, removal of heavy metals from contaminated water has become a major topic due to the toxicological problems caused by the toxic metals to the environment and to human health. Among the various removal methods, adsorption has been proven to be an efficient technology, while its large-scale application is limited by the high cost of the adsorbent. Under this situation, some raw agricultural residues materials,as low-cost adsorbents, were tested to evaluate their efficiency in the removal of heavy metals. The main objective of the present studywas to investigate the feasibility of biochars, resulted from date palms and cotton stalks slow pyrolysis process, as adsorbents for Co (II) and Ni (II) removal from polluted drainage water. The two biochars (i.e. date palms and cotton stalks) were characterized and investigated for $\mathrm{Co}$ (II) and $\mathrm{Ni}$ (II)removal from polluted waterfrom a main drain.Similarly, activated carbon (A.C.) from the date palms residues was prepared by thermal analysis as adsorbent and used for comparison with the two biochars. The results indicated that the original product biochars from slow pyrolysis process might be used as inexpensive adsorbents for water purification.

Copy Right, IJAR, 2016,. All rights reserved.

\section{Introduction:-}

Environmental pollution by toxic heavy metals is a worldwide problem due to increased industrialization. Also, irrigating crops with polluted water from open drainage channels is a common practice in urban agricultural production regions in Egypt. These heavy metals are particularly problematic due to their accumulation in the food chain and their persistence (Buenoet al., 2008). Recently, several researchers indicated that, bio-sorption of heavy metals using biological materials has been identified as a potential technique for remediation of metal bearing effluents (Babarindeet al., 2009; Babarinde and Babalola 2010;Sarma,2010; Liu et al., 2010; Sari et al., 2007; Zhang and Wang 2010; Vijayaraghavan and Balasubramanian 2010; Fiorentin et al., 2010; Qu and Zhang 2010; and Basu et al., 2010). Also, conventional methods of removing heavy metals from solutions were reported (Sari et al., 2007). There is a need to regulate heavy metals levels in the environment before they accumulate in the food and cause severe health problems. Moreover, El-Haggaret al.(2001) reported that there are almost 24 million tons/year of agricultural biomass produced in Egypt. Most of these wastes are being burned in open areas to get rid of them causing the black cloud, polluting the environment, in addition to releasing significant amounts of toxic and greenhouse gases. Agricultural wastes "cotton stalks and date palms" are available in large quantities in several parts 
of the world and produced by the farmer in Egypt (Ali et al., 2001). Biomass can be converted by thermo chemical process into valuable products. Currently, there are several thermo chemical technologies such as pyrolysis used for production biochars. Pyrolysis converts organic matters into valuable products namely: solid char (biochars), liquid (bio-oil), a gas and a high carbon. Pyrolysis involves heating of organic materials in absence of oxygen. It is simple and inexpensive process used to produce biocharsfor thousands of years (Lehmann and Joseph, 2009). Khater and Chandroppa (2006) indicated that, the particular characteristics of biochars depend strongly on their property, which is affected in turn by the pyrolysis conditions, and type of feedstock used in its production. Yield and composition of biochars products depend on pyrolysis conditions. Liang et al. (2006)stated that, biochars usually have greater sorption ability than natural soil organic matter due to their greater surface area, negative surface charge, and charge density. These characteristics make biochars an exceptional water amendment for use in sustainable agriculture (Lehmann and Joseph, 2009; and Verhejienet al., 2010).

The first goal of this study was to find a value-added utilization approach for agricultural residues. The second goal was to examine the potential use of biochars, resulted from date palms and cotton stalks slow pyrolysis process, as adsorbents for $\mathrm{Co}$ (II) and $\mathrm{Ni}$ (II) removal from polluted drainage water compared with A.C. derived from date palms.

\section{Materials and Methods:- Water samples:-}

Water samples were collected from El-Qalubia main drain at three locations namely: El-Lemon village (sample 1), El-Gendi village (sample 2), and Belbies drainrepresenting the extension of El-Qalubia main drain (sample3). The following measurements were done for the collected water samples:

a. The $\mathrm{pH}$ values were measured by $\mathrm{pH}-$ meter (CG710) according to Issam and Antonie (2007).

b. The electrical conductivity values $\left(\mathrm{mmos} . \mathrm{cm}^{-1}\right)$ were measured using a conductivity bridged meter 710 (Issam and Antonie, 2007).

c. Total contents of heavy metals $(\mathrm{Pb}, \mathrm{Co}, \mathrm{Ni}, \mathrm{Cd}$, and $\mathrm{Cr}$ ) were determined by inductively atomic spectroscopy (Issam andAntonie, 2007).

\section{Biochars and A.C. preparation:-} Biochars preparation:-

The feedstock used for preparation focused on two crop residues, i.e. date palms and cotton stalks. These waste biomass were collected from local sources, where date palms and cotton stalks were obtained from farmers fields at El-Minia governorate, Egypt. The collected samples were left to air dry and subsequently oven-dried over night at $75^{\circ} \mathrm{C}$. Certain weight of samples were added in Teflon-crucible covered with punched alumina paper in closed iron box in presence of $\left(\mathrm{NH}_{4}\right)_{2} \mathrm{CO}_{3}$ as available laboratory mean to generate $\mathrm{N}_{2}$ or $\mathrm{CO}_{2}$ gas. Then, the samples were placed in muffle, with slow pyrolysis at 250 and $400{ }^{\circ} \mathrm{C}$ for $1 \mathrm{~h}$. Finally, the samples were left to cool to room temperature (Wei Zhenget al.,2010).

\section{Preparation of active carbon (A.C.) from date palms:- Materials:-}

Prior to carbonization of the raw materials, namely date palms, the sample was left in air for partial dryness, crushed to fragments and then dried at $100{ }^{\circ} \mathrm{C}$ for $2 \mathrm{hrs}$ till constant weight. The dried crushed material was subjected to destructive distillation at $625^{\circ} \mathrm{C}$ in muffle in presence of excess $\left(\mathrm{NH}_{4}\right)_{2} \mathrm{CO}_{3}$ for $5 \mathrm{hrs}$ to obtain non-activated carbon.

\section{Preparation of steam A.C.}

The steam activated samples of date palms are prepared by gasification of non-activated carbon at $900{ }^{\circ} \mathrm{C}$ in presence of excess of $\left(\mathrm{NH}_{4}\right)_{2} \mathrm{CO}_{3}$ for $1 / 2 \mathrm{~h}$, then left to cool to room temperature. Finally, the samples were kept in a dark bottle (El-Sharkawy, 2001).

\section{Chemical analysis:-}

Chemical properties of biochars types obtained at 250 and $400{ }^{\circ} \mathrm{C}$, and A.C. of date palms including pH, E.C., and carbon and ash contents were measured. Also, the FT-IR spectra was used to investigate the oxygen-surface functional groups. Boehm (2002) titration method was used to determine the concentration of functional groups investigated. 
a. To measure the $\mathrm{pH}$ of biochars types and A.C. of date palms investigated $1 \%$ suspensions were prepared by diluting them with double ionized water, then heated to about $90{ }^{\circ} \mathrm{C}$, and stirred for 20 min. to allow the dissolution of the soluble biochars components. Finally, the $\mathrm{pH}$, and E.C.were measured according to Agusalimet al., (2010).

b. Carbon and ash contents of thesamples were determined using elemental analysis at $650{ }^{\circ} \mathrm{C}$ for $6 \mathrm{hrs}$ in open crucible (ASTM, E1755-01).

c. Surface area of thesamples were calculated from $\mathrm{N}_{2}$ adsorption isotherms by BET method using Nova 2000.

d. Concentration of oxygen-surface functional groups was determined using the barium titration method (Boehm,2002).

e. Determination of base neutralization capacity (BNC) of A.C. of date palms

The BNC was determined via the adsorption from aqueous solutions of different bases, namely $\mathrm{NaOH}_{2} \mathrm{Na}_{2} \mathrm{CO}_{3}$ , and $\mathrm{NaHCO}_{3}$, onto A.C. prepared. $0.2 \mathrm{~g}$ of the samples in $50 \mathrm{~mL}\left(0.2 \mathrm{molL}^{-1}\right)$ base was shacked for $24 \mathrm{~h}$, filtered, then titrating the filtrate using $(0.1$

molL $\left.^{-1}\right) \mathrm{HCl}$ as described by Boehm (2002).

f. The main functional groups were identified by the FT-IR spectrum("IR.Affinity ${ }^{-1}$ "FouriertransformationIR spectro- photometer, Shimadzu). The spectrainvestigated the surface carbon-oxygen groups.

\section{Batch adsorption experiments:-}

$100 \mathrm{~mL}$ of wastewater solution were taken and adjusted at $\mathrm{pH} 7$, then $1 \mathrm{~g} / 0.2 \mathrm{~g}$ of the biochars types obtained at 250 and $400{ }^{\circ} \mathrm{C}$, and A.C., respectively was added. The particle size of the biochars types prepared for this test was 125 $\mu \mathrm{m}$. The components were put in closed bottles, and shaken for $2 \frac{1}{2} \mathrm{hrs}$ at room temperature. Finally, the sorbent separated from the samples by filtration and the filtrate was analyzed using atomic spectroscopy technique according to Kilic et al., (2013).

\section{Results and Discussion:-}

Results of the mean values of pH, E.C., and heavy metals contentsin the water samples initially collected from the main drain are presented in Table1.

\section{pH values:-}

The measured $\mathrm{pH}$ values were $7.15,7.40$, and 7.35 for $1^{\text {st }}, 2^{\text {nd }}$, and $3^{\text {rd }}$ samples, respectively. Results indicated that, all $\mathrm{pH}$ values fall withinthe normal range according to the guidelines of El-Gendi (2004).

\section{Electrical conductivity (E.C.):-}

Results in Table 1 showed that the E.C. values of the initial water samples were 1.14, 0.90, and $1.44 \mathrm{mmos}^{\mathrm{cm}} \mathrm{cm}^{-1}$ for $1^{\text {st }}, 2^{\text {nd }}$, and $3^{\text {rd }}$ samples, respectively. All E.C. values fall in the acceptable range according to the guidelines of ElGendiet al., (2004). According to Ayers and Westcott (1985) who classified the quantity of saline water with respect to its total salinity (E.C.), the three samples collected fromthe three locations may cause increasing salinity problem for soil for continuous irrigation uses.

\section{Heavy metals contents:-}

The values of total $\mathrm{Ni}, \mathrm{Co}, \mathrm{Cr}, \mathrm{Pb}$, and $\mathrm{Cd}$ contents of the three samples of wastewater under investigation are presented in Table 1. Results indicated that, total Ni values were $0.76,0.86$, and $0.51 \mathrm{mmolL}^{-1}$ for $1^{\text {st }}, 2^{\text {nd }}$, and $3^{\text {rd }}$ samples, respectively. Total Co values were $0.85,0.11$, and $0.61 \mathrm{mmolL}^{-1}$ for $1^{\text {st }}, 2^{\text {nd }}$, and $3^{\text {rd }}$ samples, respectively. Results showed also that, $\mathrm{Cd}$ values were $0.021,0.025$, and $0.028 \mathrm{mmolL}^{-1}$ for $1^{\text {st }}$, of $2^{\text {nd }}$, and $3^{\text {rd }}$ samples, while $\mathrm{Pb}$ values were $0.47,0.28$, and $0.26 \mathrm{mmolL}^{-1}$ for $1^{\text {st }}, 2^{\text {nd }}$, and $3^{\text {rd }}$ samples, respectively. As for Cr contents, the measured values were zero for $1^{\text {st }}$ and $3^{\text {rd }}$ sample; while for the $2^{\text {nd }}$ sample it was $0.03 \mathrm{mmolL}^{-1}$. The obtained results showed that, the values of $\mathrm{Pb}, \mathrm{Cd}, \mathrm{Ni}, \mathrm{Co}$, and $\mathrm{Cd}$ are higher than that reported by El-Gendi et al.,(2004). The heavy metals contents can be arranged in descending order as follow:

$\mathrm{Co}>\mathrm{Ni}>\mathrm{Pb}>\mathrm{Cd} \quad$ for $1^{\text {st }}$ sample

$\mathrm{Ni}>\mathrm{Pb}>\mathrm{Co}>\mathrm{Cr} \approx \mathrm{Cd}$ for $2^{\text {nd }}$ sample

$\mathrm{Co}>\mathrm{Ni}>\mathrm{Pb}>\mathrm{Cd} \quad$ for $3^{\text {rd }}$ sample

Also, it is concluded that there was no contamination or hazard effect for $\mathrm{Pb}$, and $\mathrm{Cr}$ and not for $\mathrm{Cd}, \mathrm{Ni}$, and $\mathrm{Co}$ heavy metals. On the other hand, the obtained values were within the save range according to Kabata-Pendias and Pendias (1992) and Bowen (1979). 
Table 1:-The pH, E.C. values and concentration of heavy metals of the investigated wastewater of El-Qalubia main drain

\begin{tabular}{|c|c|c|c|c|c|c|c|c|}
\hline Sample & $\mathrm{pH}$ & E.C. & \multicolumn{7}{|c|}{ Heavy metals (mmolL } \\
& & $m m o S c m^{-1}$ & & $\mathrm{~Pb}$ & $\mathrm{Ni}$ & $\mathrm{Co}$ & $\mathrm{Cr}$ & $\mathrm{Cd}$ \\
\hline & & 1.14 & & 0.47 & 0.76 & 0.85 & - & 0.02 \\
\hline 1 & 7.15 & 0.90 & & 0.28 & 0.86 & 0.11 & 0.03 & 0.03 \\
\hline 3 & 7.40 & & & 0.26 & 0.51 & 0.61 & - & 0.03 \\
\hline
\end{tabular}

Table 2:- Recommended values of heavy metals in water according to Bowen (1979)

\begin{tabular}{|c|c|c|c|c|c|}
\hline & \multicolumn{5}{|c|}{ Heavy metals contents (mmol L $\left.{ }^{-1}\right)$} \\
\hline Metal & $\mathrm{Cd}$ & $\mathrm{Pb}$ & $\mathrm{Ni}$ & $\mathrm{Co}$ & $\mathrm{Cr}$ \\
\hline Limits & 0.01 & 0.50 & 0.20 & 0.05 & 0.10 \\
\hline
\end{tabular}

Characterization of the prepared biochars types and active carbon (A.C.):-

Generally, Chen et al.,(2016) showed that there were number of parameters affecting properties of products. These include the biomass type, biomass pretreatment (physical, chemical, and biological), reaction atmosphere, temperature, heating rate, and vapor residence time. This manuscript gives a general summary of the properties of the pyrolytic products and their analysis methods.

\section{pH values:-}

Results in Table 3 represent the measured $\mathrm{pH}$ values of the biochars types obtained at 250 and $400^{\circ} \mathrm{C}$ prepared from the biomass of date palms and cotton stalks. The average $\mathrm{pH}$ values of biochars obtained at $250{ }^{\circ} \mathrm{C}$ were 7.10 for date palms and 7.60 for cotton stalks. Also, average $\mathrm{pH}$ values of biochars types obtained at $400{ }^{\circ} \mathrm{C}$ were 7.55 for date palms and 7.70 for cotton stalks. The obtained results indicate that $\mathrm{pH}$ of biochars increased with the pyrolysis temperature. From the obtained results it could be concluded that the two biochars types obtained at $400{ }^{\circ} \mathrm{C}$ have net negative surface charge more than those obtained at $250^{\circ} \mathrm{C}$. Results presented in Table 3 showed also that, active carbon (A.C.) prepared from date palms at $900{ }^{\circ} \mathrm{C}$ has higher $\mathrm{pH}$ value 8.95 than biochars types obtained at 250 and $400{ }^{\circ} \mathrm{C}$. The results agreed with that reported by Zainabet al. (2015), who indicated that the A.C. prepared from date palms had a highly porous structure and thus it is expected to be a suitable adsorbent for heavy metals ions removal from wastewater systems.

\section{Electrical conductivity values:-}

In general, E.C. values of both biochars types obtained at 250 and $400{ }^{\circ} \mathrm{C}$, and the active carbon were found less than 1 (Table 3). The average E.C. values of biochars types obtained at $250{ }^{\circ} \mathrm{C}$ were $0.21 \mathrm{mmos} . \mathrm{cm}^{-1}$ for date palms and 0.23 mmos. $\mathrm{cm}^{-1}$ for cotton stalks. While, average E.C. values of biochars types obtained at $400{ }^{\circ} \mathrm{C}$ were 0.12 mmos. $\mathrm{cm}^{-1}$ for date palms and $0.38 \mathrm{mmos} . \mathrm{cm}^{-1}$ for cotton stalks. Also, results indicated that the E.C. value was 0.38 mmos. $\mathrm{cm}^{-1}$ for the A.C. prepared from the date palms. For the biochars obtained from date palms, the E.C. values decreased with increasing temperature, while the E.C. values decreased for the biocharsprepared from cotton stalks. According to the classification reported by Logan et al. (1997) and Al-Wableet al. (1998), biochars types obtained at 250 and $400{ }^{\circ} \mathrm{C}$, and A.C of date palms did not cause increasing in the water salinity. Zahra et al.(2015) showed that liquid-phase E.C. was very high, indicating that soluble ions were mainly separated by the effluent from the solid phase (biochars obtained at $700^{\circ} \mathrm{C}$ ) used. This led to a low concentration of soluble ions in the biochars suspension compared to sewage sludge.

\section{Carbon and ash contents:-}

Results listed in Table 3 showed that the average carbon and ash contents of both biochars types obtained at $250^{\circ} \mathrm{C}$ were $71,29,75$, and $25 \%$ for date palms and cotton stalks biochars, respectively. The values obtained at $400{ }^{\circ} \mathrm{C}$ were $75.5,24.5,77$, and $23 \%$. For the A.C. of date palms, the respective values were 85 and $15 \%$. Results indicate that, carbon contents generated from the two biochars types and A.C. type increased with temperature increase. Conley et al., (2009) reported that carboxylic and lactone groups decompose "carbonize" in the range from 200 to $700-800{ }^{\circ} \mathrm{C}$, the guanine, phenol and ether groups decompose in the range from $500-1000{ }^{\circ} \mathrm{C}$, and the phenolic groups decompose in the range from $200-300{ }^{\circ} \mathrm{C}$ to $400-500{ }^{\circ} \mathrm{C}$. 
Surface area measurements $\left(\mathbf{S}_{\mathrm{BET}}\right)$ :-

Surface areas generally increased with increasing temperature. Average surface area values measured for both biochars types obtained at 250 , and $400^{\circ} \mathrm{C}$ as well as the A.C. of date palms are presented in Table 3 . Results showed that, average surface area values of biochars types obtained at $250{ }^{\circ} \mathrm{C}$ were $1.60 \mathrm{~m}^{2} \mathrm{~g}^{-1}$ for date palms and $1.67 \mathrm{~m}^{2} \mathrm{~g}^{-1}$ for cotton stalks. While, the same respective surface area values of biochars types obtained at $400^{\circ} \mathrm{C}$ were $3.95 \mathrm{~m}^{2} \mathrm{~g}^{-1}$ and $3.99 \mathrm{~m}^{2} \mathrm{~g}^{-1}$. Results indicated that, increasing the temperature increases the surface area of the raw materials used. For the A.C. of the date palms, average surface areas was $8.87 \mathrm{~m}^{2} \mathrm{~g}^{-1}$. The obtained value was the highest as compared with biochars types obtained at 250 and 400. which reflectthe formation of fine-pore structure generated through a well-controlled activation process. The obtained results agreed with that of Chen et al. (2008), who indicated that the increased surface area of biochars and A.C. produced at higher pyrolysis temperature is attributable to the removal of $-\mathrm{OH}$, aliphatic $\mathrm{C}-\mathrm{O}$, and ester $\mathrm{C}=\mathrm{O}$ groups from outer surfaces of the feedstock.

Table 3:- Some characteristics of derived biochars at $250,400{ }^{\circ} \mathrm{C} \&$ A.C

\begin{tabular}{|c|c|c|c|c|c|}
\hline Raw materials & $\mathrm{pH}$ & $\begin{array}{c}\text { E.C } \\
m S c m^{-1}\end{array}$ & $\begin{array}{c}\mathrm{S}_{\mathrm{BET}} \\
\mathrm{m}^{2} \mathrm{~g}^{-1}\end{array}$ & $\mathrm{C} \%$ & Ash\% \\
\hline D.P 250 & 7.10 & 0.21 & 1.60 & 71 & 29 \\
\hline C.S 250 & 7.60 & 0.23 & 1.67 & 75 & 25 \\
\hline D.P 400 & 7.55 & 0.12 & 3.95 & 75.5 & 24.5 \\
\hline C.S 400 & 7.70 & 0.38 & 3.99 & 77 & 23 \\
\hline A.C of D.P & 8.95 & 0.38 & 8.87 & 85 & 15 \\
\hline
\end{tabular}

Functional groups concentration:-

The concentration of the oxygen-surface functional groups of biochars types obtained at 250 and $400{ }^{\circ} \mathrm{C}$ are represented in Table 4 . At $250{ }^{\circ} \mathrm{C}$ average surface functional groups concentration values varied from 0.270 to 0.320 mmole. $\mathrm{g}^{-1}$ for date palms, and from 0.172 to 0.219 mmole. $\mathrm{g}^{-1}$ for cotton stalks. While, biochars types obtained at $400^{\circ} \mathrm{C}$, average values varied from 0.982 to $0.983 \mathrm{mmole}^{\mathrm{g}} \mathrm{g}^{-1}$, and from 0.257 to $0.357 \mathrm{mmole} . \mathrm{g}^{-1}$ for date palms, and cotton stalks, respectively. Results indicated that, increasing the temperature, increases the concentration of the functional groups. Results indicated also that, with increasing pyrolysis temperature the concentration of functional groups increases.

\section{Base neutralization capacities:-}

It is the most simplest and convenient technique for the qualitative and quantitative identification of surface acidicgroups on the surface of A.C. type. It was found that the titration with $\mathrm{Na}_{2} \mathrm{CO}_{3}$ can neutralize carboxylic and lactonic groups, $\mathrm{NaHCO}_{3}$ neutralize the carboxylic groups, while $\mathrm{NaOH}$ neutralize all acidic groups on the surface. The base neutralization capacities of the investigated samples expressed in meq. $\mathrm{g}^{-1}$ are shown in Table 5. Results showed that the sum.of functional groups concentration related to negative surface charge of active carbon (A.C.) was higher than each biochars types obtained at 250 and $400{ }^{\circ} \mathrm{C}$. The concentration of the functional groups were 0.708 meq.g $\mathrm{g}^{-1}$ for the carboxylic and lactonic groups neutralized by $\mathrm{Na}_{2} \mathrm{CO}_{3}, 0.475$ meq. $\mathrm{g}^{-1}$ for the carboxylic groups neutralized by $\mathrm{NaHCO}_{3}$, and 0.125 meq.g ${ }^{-1}$ for all acidic groups neutralized by $\mathrm{NaOH}$.

Table 4:- Functional groups concentrations of lignocellulosicbiochars $250 \& 400{ }^{\circ} \mathrm{C}$ determined using the Barium titration method

\begin{tabular}{|l|l|}
\hline Types of biochars & \multicolumn{1}{|c|}{$\begin{array}{c}\text { Functional groups concentration } \\
\text { mmolg }^{-1}\end{array}$} \\
\hline D.P 250 & $0.270-0.320$ \\
\hline C.S 250 & $0.172-0.219$ \\
\hline D.P 400 & $0.982-0.983$ \\
\hline C.S 400 & $0.257-0.357$ \\
\hline
\end{tabular}

Table 5:- Functional groups concentrations of the A.C. of D.P.

\begin{tabular}{|c|c|c|c|}
\hline \multirow[t]{2}{*}{ A.C type } & $\mathrm{NaOH}$ & \multicolumn{2}{|c|}{$\mathrm{NaHCO}_{3}$} \\
\hline & meq.g ${ }^{-1}$ & meq. ${ }^{-1}$ & meq. $\mathrm{g}^{-1}$ \\
\hline A.C of D.P & 0.708 & 0.475 & 0.125 \\
\hline
\end{tabular}




\section{FT-IR Spectrum analysis:-}

The FT-IR analysis investigates the surface C-O groups. It is the main tool to identify these groups as some of important functional groups that lead to negative surface charge are responsible for the interaction. Results in Figs14 showed that the spectra of biochars types obtained at 250 and $400{ }^{\circ} \mathrm{C}$ were relatively similar in shape and their intensities. This is due to the fact that the lignocellulosic materials were charred at relatively low temperature, and only partial ionization occurred. The FT-IR spectrum as illustrated in Figs. 1 and 2 for date palms and cotton stalks biochars obtained at $250^{\circ} \mathrm{C}$, had a band at $3200 \mathrm{~cm}^{-1}$ stretching indicating the presence of both free alcohol-OH, Hbonding. A band at $1064 \mathrm{~cm}^{-1}$ stretching of date palms, and a band at $1049 \mathrm{~cm}^{-1}$ of cotton stalks indicates the possibility of C-O stretching, or alcohol-OH, or carboxylic acid. There was a sharp band at $2924 \mathrm{~cm}^{-1}$ of date palms that is related to C-C of alkenes. While in the FT-IR spectra of date palms and cotton stalks biochars obtained at $400^{\circ} \mathrm{C}$ (Figs 3 and 4), there was a band at $1589 \mathrm{~cm}^{-1}$ of the two biochars types which is related to C-C alkenes and aromatic rings. In addition, there are other secondary bands of both of biochars types obtained at 250 and $400^{\circ} \mathrm{C}$ related to more substituted $\mathrm{C}=\mathrm{N}, \mathrm{NO}_{2}$, ---- etc. Results of the FT-IR analysis indicate the similarity in the main functional groups and the properties of date palms and cotton stalks biochars prepared at 250 and $400^{\circ} \mathrm{C}$. The FT-IR spectrum of the A.C. from date palms type showed a band at $1100 \mathrm{~cm}^{-1}$ which is related to the possibility of the presence of $\mathrm{C}-\mathrm{O}$ stretching. This band is a predominant band that is considered as an important functional group and the responsible for interactions that may be occurred. Also, there were other bands of the A.C.type related to other secondary groups. The obtained results agree with those of Chen (2008) and Chun et al. (2004), who reported that the absence of significant adsorption bands in the spectrum of A.C. suggests that the graphic structure is symmetrical and little change in dipole moment occurs during vibration.

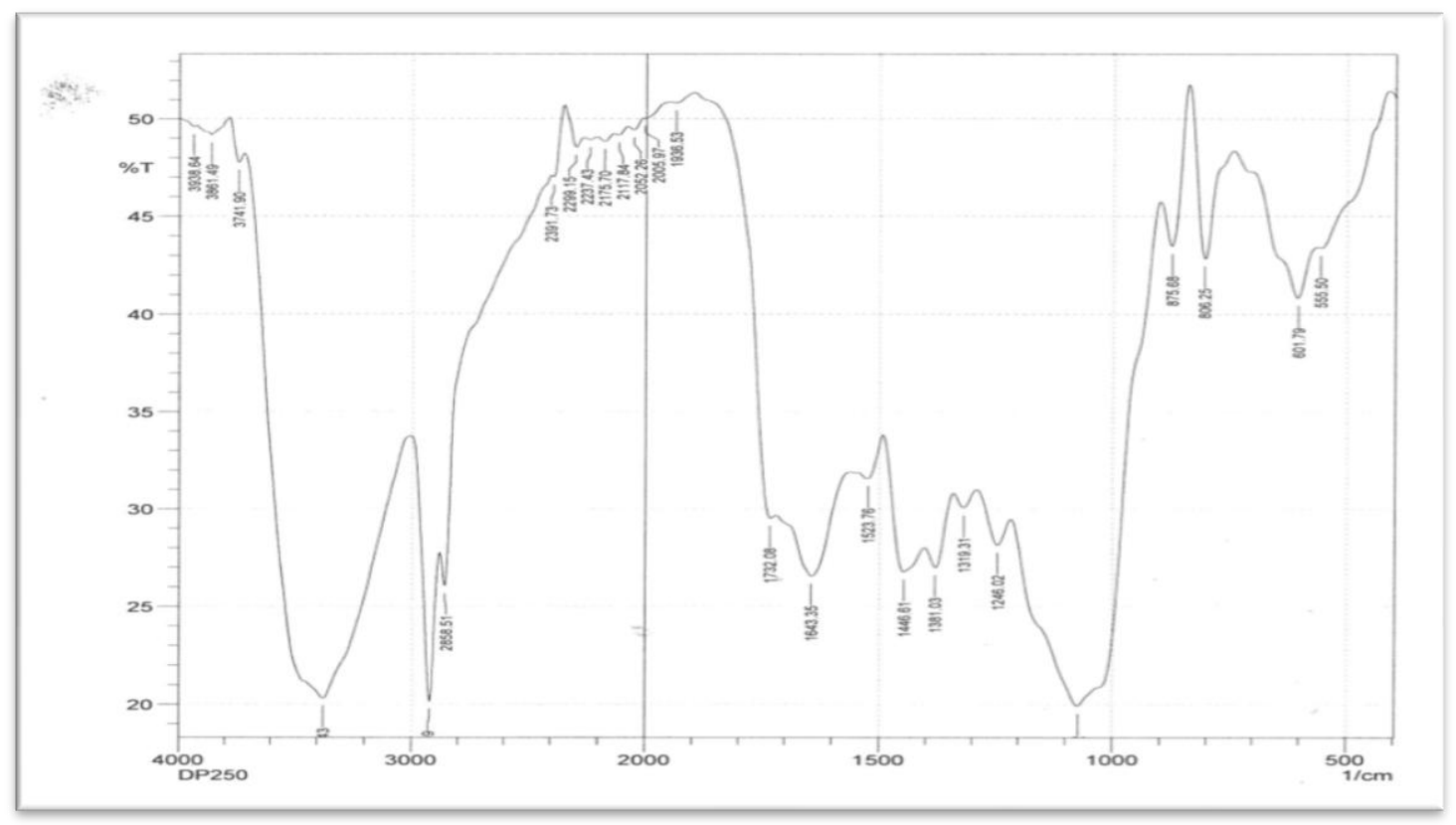

Fig.1. FT-IR spectrum of D.P 250 


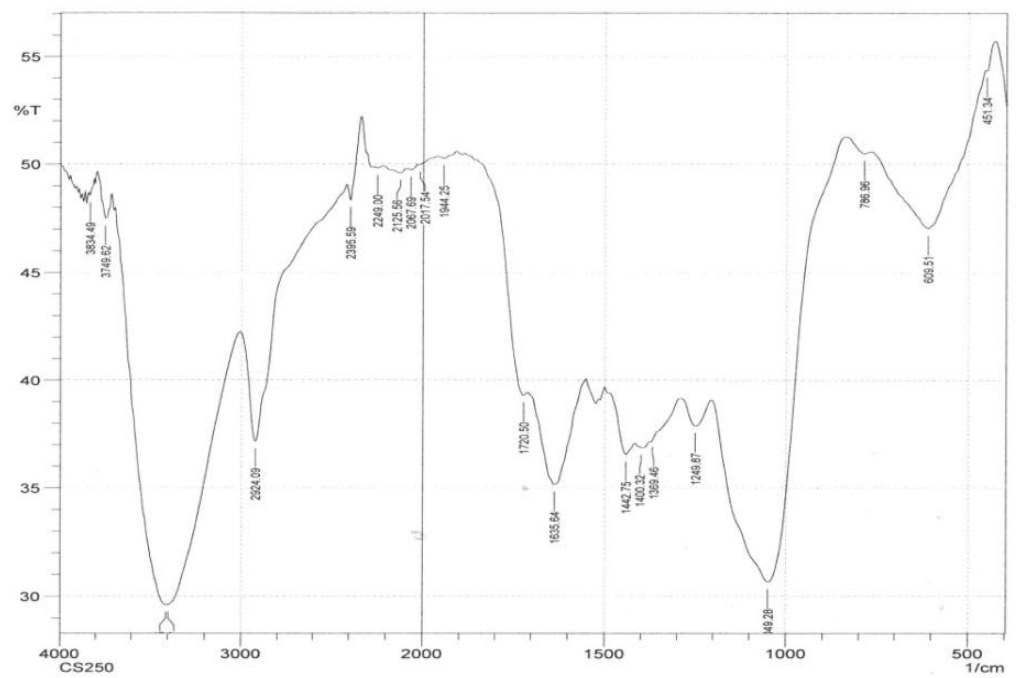

Fig. 2:- FT-IR spectrum of C.S 250.

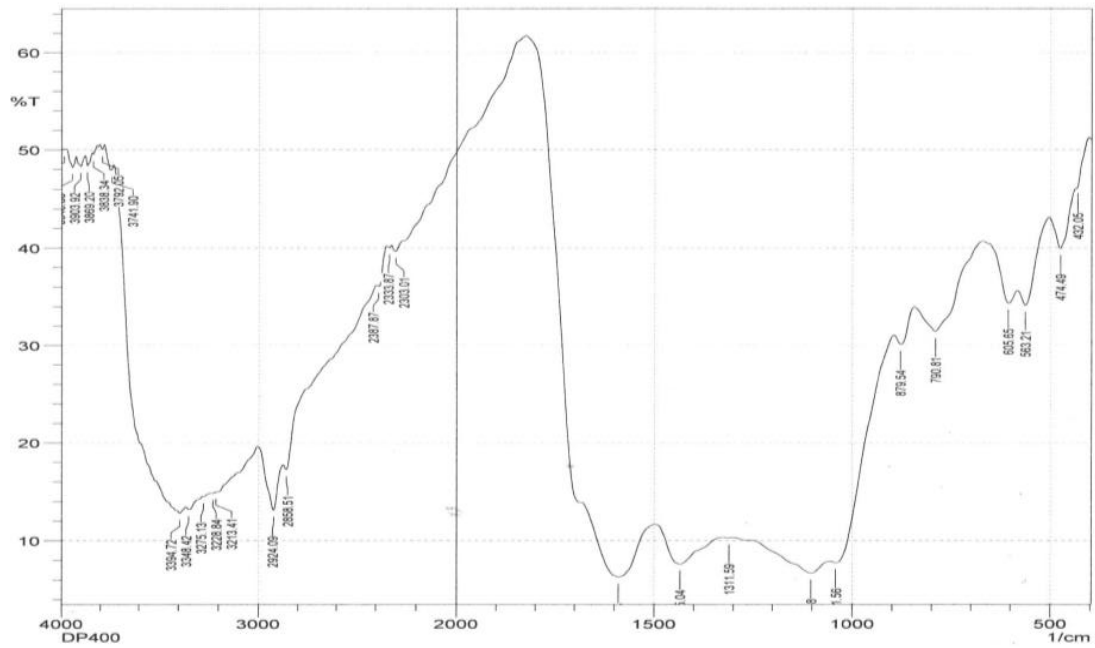

Fig.3:- FT-IR spectrum of D.P 400

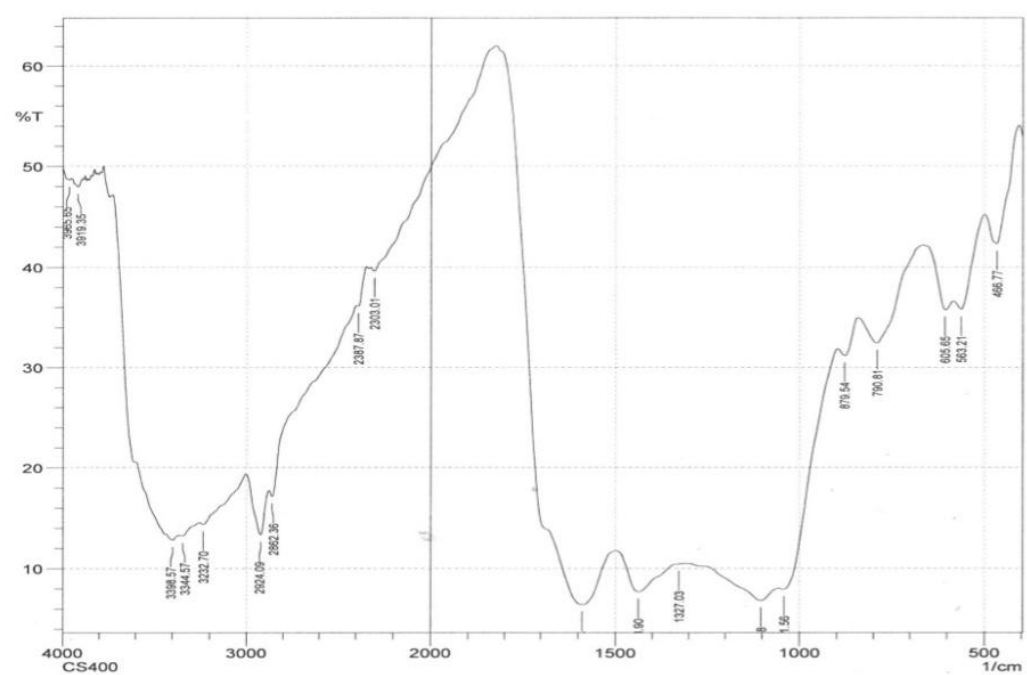

Fig.4:- FT-IR spectrum of C.S 400 


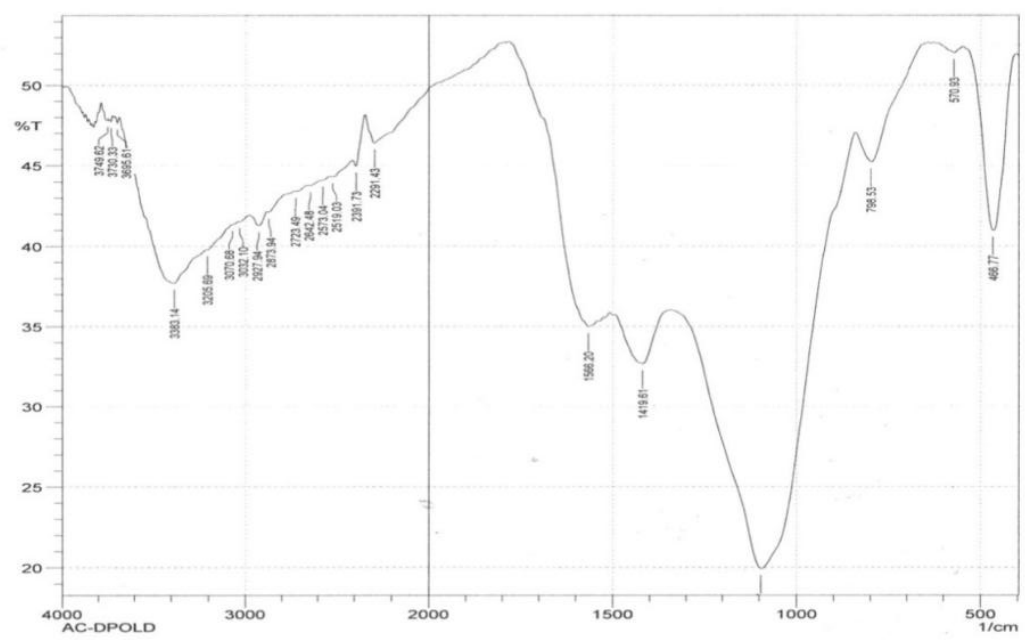

Fig.5. FT-IR spectrum of A.C of D.P

Wastewater remediation using biochars types and A.C of date palms:-

Results indicated that both date palms and cotton stalks biochars obtained at 250 and $400{ }^{\circ} \mathrm{C}$, and A.C. of date palms affected the physical properties of the wastewater samples under study by removing their color, odor, and suspended matters. The obtained results are due to the development of surface basic groups of the used biochars and the more basic character of the active carbon. The results were agree well with those reported by Nancharaiah (2011), Namasivayam (2006), Yin (2007), and Demiral (2010), who reported that biochars and active carbon materials are widely used in the removal of several different organic and inorganic pollutants from wastewater.

\section{$\mathrm{Ni}$ (II), and Co (II) adsorption:-}

Results in Table 6 showed $\mathrm{Ni}$ (II) and Co (II) adsorption at pH 7 and their removal percentage as compared to the initial conditions. It was noticed that both biochars types obtained at 250 and $400{ }^{\circ} \mathrm{C}$ had the same efficiency of Co (II) removal, but results were different for Ni (II). The removal reached $100 \%$ for Co (II) for both biochars obtained at 250 and $400^{\circ} \mathrm{C}$. For the biochars prepared from date palms, Ni (II) concentrations and the removal values were $0.113 \mathrm{mmolL}^{-1}(84.9 \%)$ and $0.12 \mathrm{mmolL}^{-1}(84 \%)$ at 250 and $400^{\circ} \mathrm{C}$, respectively. While, for the biochars prepared from cotton stalks, $\mathrm{Ni}$ (II) adsorption increased with increasing temperature. $\mathrm{Ni}$ (II) concentrations and the removal values were $0.197 \mathrm{mmolL}^{-1}(73.7 \%)$ and $0.09 \mathrm{mmolL}^{-1}(88 \%)$ at 250 and $400{ }^{\circ} \mathrm{C}$, respectively.

There are two mechanisms, specific (inner-sphere complexation) and nonspecific (outer- sphere complexation) between anionic ligand adsorbed onto metal oxides. Outer-sphere complexation will form a neutralized surface as an anion coordinates to a protonated hydroxyl on the adsorbent surface. Anions complexed in the outer-sphere of a metal oxide are readily exchangeable and free to move in solution and no complex is formed with surface functional groups. Hydroxyl ligand exchange can occur after surface pretention, which is known as inner-surface complexation (Tor and Cengeloglu.2006). All such interactions can be occurred between metal ions and biochars as adsorption mechanism (Mohan et al. 2014). The adsorption capability of the biocharspyrolyzed at $200{ }^{\circ} \mathrm{C}$ exceeded that of pyrolyzed samples at higher temperatures (Li., (2016).

There are several interpretations of the variation of Ni (II), and Co (II) adsorption ratios. The first is that may be due to Co (II) prefers reaction with basic groups "as predominant groups" of Alcohol-OH and C-O or COO groups of date palms, and cotton stalks biochars obtained at $250^{\circ} \mathrm{C}$ rather as well as than that of $\mathrm{C}$-C "alkenes" as predominant groups" of the corresponding biochars obtained at $400^{\circ} \mathrm{C}$ forming stable complex with respect to $\mathrm{Ni}$ (II) as mentioned previously in FT-IR analysis. The second interpretation may be attributed to the high affinity, and selectivity of Co (II) with respect to Ni (II). This behavior is explained according to hard-soft acid-base rule (Pulls and Boehn, 1988; Prada's et al.,1994). The third onemay be due to the basic character of biochars related to the functional groups ; the mean responsible of interactions, leads to preferring combination with Co (II) as central atom with biochars type as ligand rather than Ni (II) forming stable complex.

Also, results in Table 6 showed that the active carbon type had the same efficiency of Co (II) removal compared with $\mathrm{Ni}$ (II) removal. Adsorption ratio at $\mathrm{pH} 7$ reached maximum of $100 \%$ for $\mathrm{Co}$ (II), while it reached $84 \%$ for $\mathrm{Ni}$ 
(II). Maximum adsorption occurred at $\mathrm{pH} 7$ because overall surface charge of A.C. type prepared have highly net negatively charged correlated to its active sites. $\mathrm{pH}$ affects the adsorption as well as that related to the ionization degree of the acidic or basic compound (El-Zayat and Edwars, 2009). This ability to chelate the different molecules is mainly due to its higher specific surface area (Saudi Embassy, 1997). The mixed heavy metals compete with each other during the adsorption process on A.C. prepared (Mohamed and Edwars, 2015).

Table 6:-Ni (II) and Co (II) concentrations in the remediated wastewater of El-Qalubia main drain by the biochars types and the A.C determined at $\mathrm{pH} 7$

\begin{tabular}{|l|c|c|c|c|}
\hline \multicolumn{1}{|c|}{ Biomass type } & \multicolumn{2}{|c|}{ Ni(II) } & \multicolumn{2}{c|}{ Co(II) } \\
\hline & Conc. $\left(\mathrm{mmolL}^{-1}\right)$ & Removal (\%) & Conc. $\left(\mathrm{mmolL}^{-1}\right)$ & Removal (\%) \\
\hline D.P 250 & 0.113 & 84.9 & - & 100 \\
\hline C.S 250 & 0.197 & 73.7 & - & 100 \\
\hline D.P 400 & 0.120 & 84.0 & - & 100 \\
\hline C.S 400 & 0.090 & 88.0 & - & 100 \\
\hline A.C of D.P & 0.120 & 84.0 & - & 100 \\
\hline
\end{tabular}

pH effect on Co (II), and Ni (II) adsorption:-

Since $\mathrm{pH}$ is one of the main variable affecting the sorption process, beside the adsorbent dosage, contact time, particle size, room temperature, it has influence not only on the metal ions speciation, but also the surface charge of the sorbent and ionization degree of the adsorbateduring the reaction (Yu et al., 2013). Ni (II) and Co (II) adsorption was carried out at $\mathrm{pH} 7$ and the results given in table 6 .

\section{Conclusion:-}

In this study biochars, an original product of pyrolysis process prepared at 250 and $400{ }^{\circ} \mathrm{C}$, were evaluated as an alternative low-cost adsorbent for $\mathrm{Ni}$ (II) and Co (II) ions removal from wastewater solutions besides A.C of date palms for comparison. Optimum adsorption conditions were determined as a function of $\mathrm{pH} 7$, adsorbent dosage $1 / 0.2 \mathrm{gL}^{-1}$ ofbiochars types and A.C type, respectively. The particle size of the biochars types was $125 \mu \mathrm{m}$, and contact time $2 \frac{1}{2} \mathrm{~h}$ at room temperature for $\mathrm{Ni}$ (II) and Co (II) removal. Maximum adsorption reached $100 \%$ for Co (II) and $84.9 \%$ for Ni (II).

\section{References:-}

1. Ali, M., M. Byrd, and H. Jam. (2001). Soda-AQ pulping of cotton stalks. Proceedings Tappi Pulping of Conference, Seattle, USA.

2. Agusalim, M., J. Kom, H. H. Wani, and J. Veternan. (2010). Rice husk bio-char for rice based cropping system in acid soil, the characteristics of rice husk bio-char and its influence the properties of acid sulfate soils and rice growth in West Kalimantan, Indonesia. Journal agric. science. Vol. 2 (1).

3. Ayers, R., and S. Westcott. (1985). Water quality for agriculture. Irrigation and Drainage Paper no. 29, FAO. Rome, Italy.

4. Ayers, R., and S. Westcot. (1980). Influences of adjusted SAR of the irrigation water upon the SAR of saturation extracts from Pakistani soils after three years of cropping. Soil Sci. 106: 29-34.

5. Al-Wabel, M.I., A.M. Al-Morin, A.A. Shalaby, and M.L. Chouldhary. (1998). Effect of sewage on some chemical properties of calcareous sandy soils-common. Soil Sci., Plant anal. 29: 17-18.

6. ASTM. (2008). Stander Test Method for ash in biomass. ASTM Committee on Standers, ASTM E1755-01, ASTM.

7. Adesola, J. Babalola, John, O. Adebola, O. Susan, Adetayo, and Emmanuel. (2013). Biosorption of Ni (II), Cr (III), and Co (II) from solutions using acalyphahispida leaf: Kinetics, equilibrium, and thermodynamics. Hindawi Publishing Corporation Thermodynamics. Hindawi Publishing Corporation Journal of Chemistry, pp 8.

8. Bueno, B.Y.M., M.L. Rorem, F. Molina, and L.M.S. de Mesquita. (2008). Biosorption of Lead (II), Chromium (III), and Copper (II) by R. opacus: Equilibrium and kinetic studies. Minerals Engineering. Vol. 21 (1): 65-75.

9. Boehm, H.P. (1994). Some aspects of the surface chemistry of carbon Blacks and other carbons. Carbon. 32: 759-769.

10. Boehm, H.P. (2002). Surface oxides on carbon and their analysis: A critical assessment. Carbon. 40: 145-149.

11. Bowen, H.J.M. (1979). Environmental chemistry of the elements. New York: Academic Ed. 
12. Babarinde, N.A.A., J.O. Babalola, A.O. Ogunfowokan, and A.C. Onabanjo. (2009). Kinetic, equilibrium, and thermodynamic studies of the biosorption of Cadmium (II) from solution by Stereo phyllumradiculosum, Toxicological and Environmental Chemistry. Vol. 91 (5): 911-922.

13. Babarinde, N.A.A., and J.O. Babalola. (2010). Kinetic, equilibrium and thermodynamic studies of the biosorption of $\mathrm{Ca}$ (II) and $\mathrm{Pb}$ (II) from solutions using Siam leaf (Chromolaenaodorata). International Review of Chemical Engineering. Vol. 2 (1): 18-24.

14. Basu, T., K. Gupta, and U.C. Ghosh. (2010). Equilibrium and thermodynamics on arsenic (III) sorption reaction in the presence of background ions occurring in groundwater with nano-particle agglomerates of hydrous iron (III) + chromium (III) mixed oxide. Journal of Chemical and Engineering Data. Vol. 55 (5): 2039-2047.

15. Chun, Y., G. Sheng, C.T. Chiou, and B. Xing. (2004). Compositions and Sorptive properties of crop residuederived chars. Environ. Sci. Technol. 38(17).

16. Chen, B., D. Zhou, and L. Zhu. (2008). Transitional adsorption and partition of non-polar and polar aromatic contaminants by biochars of pine needles with different pyrolytic temperature. Environ. Sci. Technol. 42: 51375143.

17. Chen, Y., J. Duan, and Y. Luo. (2008). Investigation of agricultural residues pyrolysis behavior under inert and oxidative conditions. J. Anal. Appl. Pyrolysis. 83: 165-174.

18. Chen, Wei-Hsin Lin, and B. Jhih. (2016). Characteristics of products from the pyrolysis of oil palm fiber and its pellets in nitrogen and carbon dioxide atmospheres. Journal of Energy. Vol. 94: 578.

19. Conley, D.J., H.W. Pearly, R.W. Howarth, D.F. Bosh, S.P. Seitzinger, K.E. Havens, C. Lancelot, and G.E. Likens. (2009). Controlling eutrophication: nitrogen and phosphorus. Science. 323(5917): 1014-1015.

20. Demiral, H., and G. Gündüzoglu. (2010). Removal of nitrate from aqueous solutions by activated carbon prepared from sugar beet bagasse. Bio-resource Techno. 101(6): 1675-80.

21. El-Haggar, S.M., M. Ghribi, and G. Longo. (2001). Agricultural waste as an energy source in developing countries: A case study in Egypt on the utilization of agricultural waste through complexes.

22. El-Sharkawy, E.A. (2001). Removal of heavy metals via adsorption on activated carbon synthesized from solid wastes. Ads. Sci. and Technol. 19: 795.

23. El-Gendi, S.A., A.H.M. Somaia, M. Abu-Sinna, and N.F. Kandil. (2004). Fractionation and accumulation of some heavy metals in soil and plant irrigated with sewage effluent. Egypt, J. Soil Sci. 39(2): 211-221.

24. El-Zayat, M., and E. Edwards. (2009). Removal of heavy metals by using activated carbon produced from cotton stalks. American University Cairo, Egypt.

25. Fiorentin, L.D., D.E.G. Trigueros, and A.N. Módenes. (2010). Biosorption of reactive blue 5G dye onto drying orange bagasse in batch system: kinetic and equilibrium modeling, Chemical Engineering Journal. Vol. 163 (12): $68-77$.

26. Issam I.B., and A.H. Sayegh. (2007). Methods of analysis for soils of Arid and Semi-Arid regions. FAO.

27. Khater, H. and G.T. Chandroppa. (2006). Impact of heavy metals contamination of bellandur lake on soil cult rated vegetation. Current Science. Vol. 91 (5): 622-627.

28. Kabata-Pendias, A., and H. Pendias. (1992). Trace elements in soils, $2^{\text {nd }}$ Ed. CRC Press, Inc. Boca Raton, Ann Arbor, London, UK.

29. Kilic, M., C. Kirbiyik, C.O. Pütün, and E. Ayse. (2013). Adsorption of heavy metals ions from aqueous solutions by bio-char, a by-product of pyrolysis. Applied Surface Science. 283: 856-862.

30. Liang, B., J. Lehman, D. Solomon, J. kinyangi, J.Grossman, B. O`Neill, and J.O. Skjemstad. (2006). Black carbon increases cation exchange capacity in soil. Soil. Sci. Soc. Am. J. 70: 1719-1730.

31. Lehmann, J., and S. Joseph (Ed). (2009). Biochars for environmental management science and technology, Earth scan: sterling.

32. Logan, T.J, B.J. Lindsay, L.E. Gouris, and J.A. Rayan. (1997). Field assessment of sludge metal bioavailability to crops: Sludge rate response. J. Environs. Qual. 26: $534-555$.

33. Liu, Y., X. Sun, and B. Li. (2010). Adsorption of $\mathrm{Hg}^{2+}$ and $\mathrm{Cd}^{2+}$ by ethylene-diamine modified peanut shells. Carbohydrate Polymers. Vol. 81 (2): 335-339.

34. Li, Gu. (2016). Adsorption of MB by wheat straw biochars enhanced by a magnetic field. Bio-resource Technology. Vol. 206: 1-304.

35. Mohan, D., A. Sarswat, Y.S. Ok, and C.U. Pittman Jr. (2014). Organic and inorganic contaminants removal from water with biochars, a renewable, low cost and sustainable adsorbent - a critical review. Bioresource Technology. 160:191-202.

36. Mohamed and S. Edwards. (2015). Removal of heavy metals by using activated carbon produced from cotton stalks. Environmental Engineering Program, the American University in Cairo. 
37. Nancharaiah Y.V., and V.P. Venugopalan. (2011). Denitrfication of synthetic concentrated nitrate wastes by aerobic granular sludge under anoxic conditions. Chemosphere. 85(4): 683-8.

38. Namasivayam, C., and D. Sangeetha. (2006). Recycling of agricultural solid waste coir pith removal of anions, heavy metals, organics and dyes from water by adsorption on to $\mathrm{ZnCl}_{2}$ activated coir pith carbon. J. Hazard Matter. 135(1-3): 449-452.

39. Puls, R.W., and H.L. Bohn. (1988). Sorption of Cads, Ni, and Zn by kaolinite and montmorillonite suspensions. Soil Sci. Society of American Journal. 52: 1289-129.

40. Pradas, E.G., M.V. Sanchez, E.C. Cruse, M.S. Viciana, and M.F Perez. (1994). Adsorption of Cd and Zn from aqueous solution on natural and activated bentonite. Journal of Chemical Technology and Biotechnology. 58: 289-295.

41. Saudi Embassy. (1997). The "Cherished Date Palm", Saudi Arabia. Vol. 13 (4).

42. Sari, M.T., O.D. Ultuziöü, and M. Soylak. (2007). Bio sorption of Pb(II) and Ni(II) from aqueous solution by Lichen (Cladoniafurcata) Biomass. Biochem. Eng. J. 37:151-158.

43. Sarma, N. S., P. Chakravarty, and H. P. Sarma. (2010). Biosorption of cadmium(II) from aqueous solution using heartwood powder of Areca catechu. Chemical Engineering Journal, Vol. 162 (3): 949-955.

44. Tor, A., and Y. Cengeloglu. (2006). Removal of Congo red from aqueous solution by adsorption on to acid activated red-mud. Journal of Hazardous Materials. 138(2): 409-415.

45. Verhejien, F., S. Jadedly, A. Bastos, C.M. Van dervelde, and I. Ideas. (2010). Biochars application to soils, JRC Scientific and Technical Reports: Institute for Environment and Sustainability, European Communities.

46. Vijayaraghavan, K., and R. Balasubramanian. (2010). Single and binary biosorption of cerium and europium onto crab shell particles, Chemical Engineering Journal. Vol. 163(3): 337-343.

47. Wei Zheng, B.K. Sharma, and K.R. Nanda. (2010). Using bio-char as a soil amendment for sustainable agriculture. ISTC/UIUC., 1E Hazel Wood Drive. Champaign, IL 6820, USA.

48. Yin, C.Y., M.K. Aroua, and D. WMAW. (2007). Review of modifications of activated carbon for enhancing contaminant uptakes from aqueous solutions, Sep. Purify Tech. 52(3): 403-15.

49. Yu, J.X., L.Y. Wang, R.A. Chi, Y.F. Zhang, Z.G. XU, and J. Guo, (2013). Competitive adsorption of $\mathrm{pb}^{2+}$ and $\mathrm{Cd}^{2+}$ on magnetic modified sugar cane bagasse prepared by two simple steps. Appl. Surf. Sci. 268:163-170.

50. Zahra K., A. Majid, and R. Mohammad. (2015). Effect of pyrolysis temperature on chemical and physical properties of sewage sludge biochars. Waste Management \& Research. Vol. 33(3): 275-283.

51. ZainabM.A., and J.Y. Qimimg. (2015). Date Palm (Phoenix DactyliferaL.) seed characterization for biochars preparation. The 6 International Conference on Engineering Project and Production Management 2-4, Gold Cost, Australia.

52. Zhang, J., and A. Wang. (2010). Adsorption of $\mathrm{Pb}(\mathrm{II})$ from aqueous solution by chitosan-g-poly (acrylic acid)/attapulgite/sodium humate composite hydromel. Journal of Chemical and Engineering Data, Vol. 55(7): 2379-2384. 